Reprod. Nutr. Dévelop., 1986, 26 (1 A), 65-76.

\title{
Modulation of juvenile rat ovarian adenylate cyclase activity by calcium and calmodulin
}

\author{
Colette TERTRIN-CLARY, Marguerite ROY, P. de la LLOSA
}

Laboratoire des Hormones Polypeptidiques, C.N.R.S. $91190 \mathrm{Gif} /$ Yvette, France.

Summary. The involvement of calcium and calmodulin in the regulation of juvenile rat ovarian adenylate cyclase activity was investigated. Both basal and LH-stimulated cAMP production were inhibited by adding $\mathrm{Ca}^{2+}$ to the incubation medium at concentrations higher than $10^{-5} \mathrm{M}$. Conversely, up to $10^{-3} \mathrm{M}$ concentrations of EGTA increased cAMP production (basal, stimulated by $\mathrm{LH}, \mathrm{FSH}, \mathrm{NaF}$ and $\mathrm{Gpp}(\mathrm{NH}) \mathrm{p}$ ); higher concentrations of the chelator led to an inhibition of cAMP formation.

However, when the homogenates were previously deprived of $\mathrm{Ca}^{2+}$ by treatment with buffer containing EGTA, a biphasic response to $\mathrm{LH}$ and $\mathrm{Gpp}(\mathrm{NH}) \mathrm{p}$ stimulation was obtained in the presence of increasing concentrations of added $\mathrm{Ca}^{2+}$ : cAMP production was first enhanced at low concentrations and then inhibited at higher concentrations. These observations suggest that the optimal concentration of $\mathrm{Ca}^{2+}$ needed to obtained maximal stimulation of the enzyme was much lower than the $\mathrm{Ca}^{2+}$ content in the homogenates and that a minimal concentration of $\mathrm{Ca}^{2+}$ was required to activate it.

In the presence of micromolar concentrations of trifluoperazine and pimozide, two potent inactivators of calmodulin, LH-stimulated cAMP production was markedly decreased. Reactivation was obtained by adding exogenous calmodulin to the assay medium.

The addition of $\mathrm{Ca}^{2+}$-free exogenous calmodulin $\left(10^{-6} \mathrm{M}\right)$ caused a specific and significant enhancement of CAMP accumulation induced by an optimal dose of $\mathrm{LH}$.

These results suggest that calcium ions regulated the adenylate cyclase activity in the rat ovaries and had a dual effect that was first stimulatory at low concentration and mediated by calmodulin and then inhibitory at high (non-physiological) concentration.

\section{Introduction.}

In many hormonally regulated systems in which cAMP has been implicated as a second messenger, $\mathrm{Ca}^{++}$ions appear to play an important role in the modulation of hormonal stimulus and cellular response, Calmodulin an ubiquitous $\mathrm{Ca}^{++}$-binding protein, is believed to mediate many intracellular calcium activities in a variety of cells. Several calmodulin-sensitive forms of adenylate cyclase have been described in different tissues. In the case of the gonads, for instance, it was reported that the basal adenylate cyclase activity of hamster ovary cell membranes was inhibited by low concentrations of calmodulin (Evain et al., 1979). From recent studies carried out on pig granulosa cells, Veldhuis and Klase 
(1982a) presented evidence that calmodulin regulatory action may be exerted at several levels, including LH-stimulated cAMP accumulation. Recently it was also reported that $\mathrm{Ca}^{+}+$ions could be involved in the $\mathrm{FSH}$ regulation of granulosa cell steroidogenesis at the level of CAMP production (Tsang and Carnegie, 1983). In rat luteal cells, Dorflinger et al. (1984) observed that an acute increase in intracellular $\mathrm{Ca}^{+}+$inhibited $\mathrm{LH}$ activation of adenylate cyclase. In the present study, we investigated the role of $\mathrm{Ca}^{+}+$ions and calmodulin, $\mathrm{a} \mathrm{Ca}^{+}{ }^{+}$-dependent modulator, in the regulation of the response of juvenile rat ovarian adenylate cyclase to $\mathrm{LH}$ and to some other effectors such as FSH, NaF and Gpp (NH)p.

\section{Material and methods.}

Material. - A highly purified $(2 \times \mathrm{LH}-\mathrm{NIH}$ S11) preparation of ovine LH was prepared in our laboratory (Jutisz and Courte, 1968). Ovine FSH was kindly provided by NIADDK, NIH $\left(20 \times \mathrm{FSH}-\mathrm{NIH}\right.$ S1). $\mathrm{Ca}^{+{ }_{-}}$-saturated bovine brain calmodulin was supplied by Fluka (Switzerland). In some experiments $\mathrm{Ca}^{+{ }^{+}}$-free calmodulin, prepared by dialysis of the commercial sample against $1 \mathrm{mM}$ ethyleneglycol-bis ( $\beta$-aminoethyl ether) $N, N^{\prime}$ tetra acetic acid (EGTA) and $10 \mathrm{mM}$ Tris- $\mathrm{HCl}$ buffer, $\mathrm{pH} 7.4$, was used. Trifluoperazine was a generous gift of the Theraplix Laboratory (Gien, France) and pimozide was provided by Janssen Laboratories (Paris). Parvalbumin, troponin, 5' guanylimidodiphosphate $(\mathrm{Gpp}(\mathrm{NH}) \mathrm{p})$ and EGTA were purchased from Sigma. Theophylline was obtained from Serva and the other products from Boehringer.

Methods. - The preparation of the homogenates and the experimental conditions of incubation have been previously described (Tertrin-Clary et al., 1980). 24-day old Sprague-Dawley rats were killed and the ovaries rapidly excised and minced. Using a loose-fitting glass homogenizer, the ovaries were homogenized in $10 \mathrm{mM}$ Tris- $\mathrm{HCl}$ buffer, $\mathrm{pH} 7.4$, containing $10 \mathrm{mM} \mathrm{MgCl}$ and $100 \mathrm{mM}$ sucrose. The homogenate $(100 \mathrm{mg}$ of wet tissue $/ \mathrm{ml}$ of buffer) was filtered through two layers of cheese cloths. The incubation medium for adenylate cyclase contained $25 \mathrm{mM}$ Tris- $\mathrm{HCl}$ buffer, $\mathrm{pH} 7.4,3 \mathrm{mM} \mathrm{MgSO}, 2.5 \mathrm{mM} \mathrm{NaCl}$, $0.1 \mathrm{mM}$ GTP, $0.6 \mathrm{mM}$ ATP, bovine serum albumin $0.12 \%, 11 \mathrm{mM}$ phosphoenol pyruvate, pyruvate kinase $80 \mu \mathrm{g} / \mathrm{ml}, 8 \mathrm{mM}$ theophylline. We checked that in these conditions the phosphodiesterase activity was completely inhibited. The reaction was started by adding the homogenate $(500 \mu \mathrm{g}$ of protein). In some experiments the homogenate was suspended in $10 \mathrm{mM}$ Tris- $\mathrm{HCl}$ buffer, $10 \mathrm{mM} \mathrm{MgCl}$, $100 \mathrm{mM}$ sucrose containing $2 \mathrm{mM}$ EGTA. After centrifugation $(5000 \mathrm{trs} / \mathrm{min}$ for $15 \mathrm{~min}$ ) the precipitate was resuspended in $10 \mathrm{mM}$ Tris- $\mathrm{HCl}$ buffer and this washing procedure was repeated again. The reaction was allowed to proceed for $15 \mathrm{~min}$ at $37^{\circ} \mathrm{C}$ and was stopped by the addition of trichloracetic acid. After centrifugation and extraction with diethyl ether, the aliquots were taken and cAMP accumulation was determined by Gilman's method (1970). The figures shown below were traced with the mean value and SEM of three determinations, and the results were confirmed by at least three different assays. 
Results.

Effects of $\mathrm{Ca}++$ and EGTA addition on the CAMP production of rat ovary homogenates. - The addition of more than $10^{-5} \mathrm{M} \mathrm{Ca}^{++}$ions to an incubation medium of juvenile rat ovary homogenates decreased the basal and the $\mathrm{LH}$ stimulated adenylate cyclase activities (fig. 1).



FIG. 1 - Influence of the addition of various concentrations of $\mathrm{Ca}^{2+}$ ions on basal $(-\cdots)$ and LH-stimulated (2.6.10-6 M) CAMP accumulation (-_) in rat ovary homogenates. The reaction was initiated by, the addition of the homogenate $(500 \mu \mathrm{g}$ of protein) and proceeded for $15 \mathrm{~min}$ at $37^{\circ} \mathrm{C}$. Results are means \pm SEM of three determinations.

In contrast, the addition of EGTA increased both the basal production of cAMP and the adenylate cyclase stimulation induced by $\mathrm{LH}, \mathrm{FSH}$, fluoride and $\mathrm{Gpp}(\mathrm{NH}) \mathrm{p}$ (the non-hydrolysable analog of GTP) (fig. 2). The response curves in relation to chelator concentration were similar for the different effectors; increasing concentrations of EGTA first had a stimulatory effect up to $1 \mathrm{mM}$ and then an inhibitory effect at higher concentrations. When $\mathrm{Ca}^{++}$was added to a medium containing an optimal concentration of EGTA $\left(10^{-3} \mathrm{M}\right.$, maximal response in fig. 2), the level of cAMP reached corresponded, as expected, to a lower concentration of EGTA. In the same manner, the addition of EGTA to a supraoptimal concentration of $\mathrm{Ca}^{++}$(see fig. 1) led to the recovery of a higher CAMP production. However, at high EGTA concentrations $(50 \mathrm{mM})$, the addition of $\mathrm{Ca}^{+}+$could not reestablish a higher cAMP production. Even when up to $50 \mathrm{mM} \mathrm{Mg}{ }^{2}$ was added to the medium, the inhibitory effect observed with a high dose of EGTA was not suppressed, showing that it was not due to the removal of this cation. It might have resulted from the disturbing effect of EGTA on the membranes (Pinkus et al., 1983). The inhibitory effect observed at 
concentrations of EGTA between $5.10^{-3} \mathrm{M}$ and $10.10^{-3} \mathrm{M}$ suggests that a minimal concentration of $\mathrm{Ca}^{+}+$was required to activate adenylate cyclase.

When the experiments were carried out with homogenates prepared in $2.10^{-3} \mathrm{M}$ EGTA buffer and extensively washed to eliminate the excess chelator, a
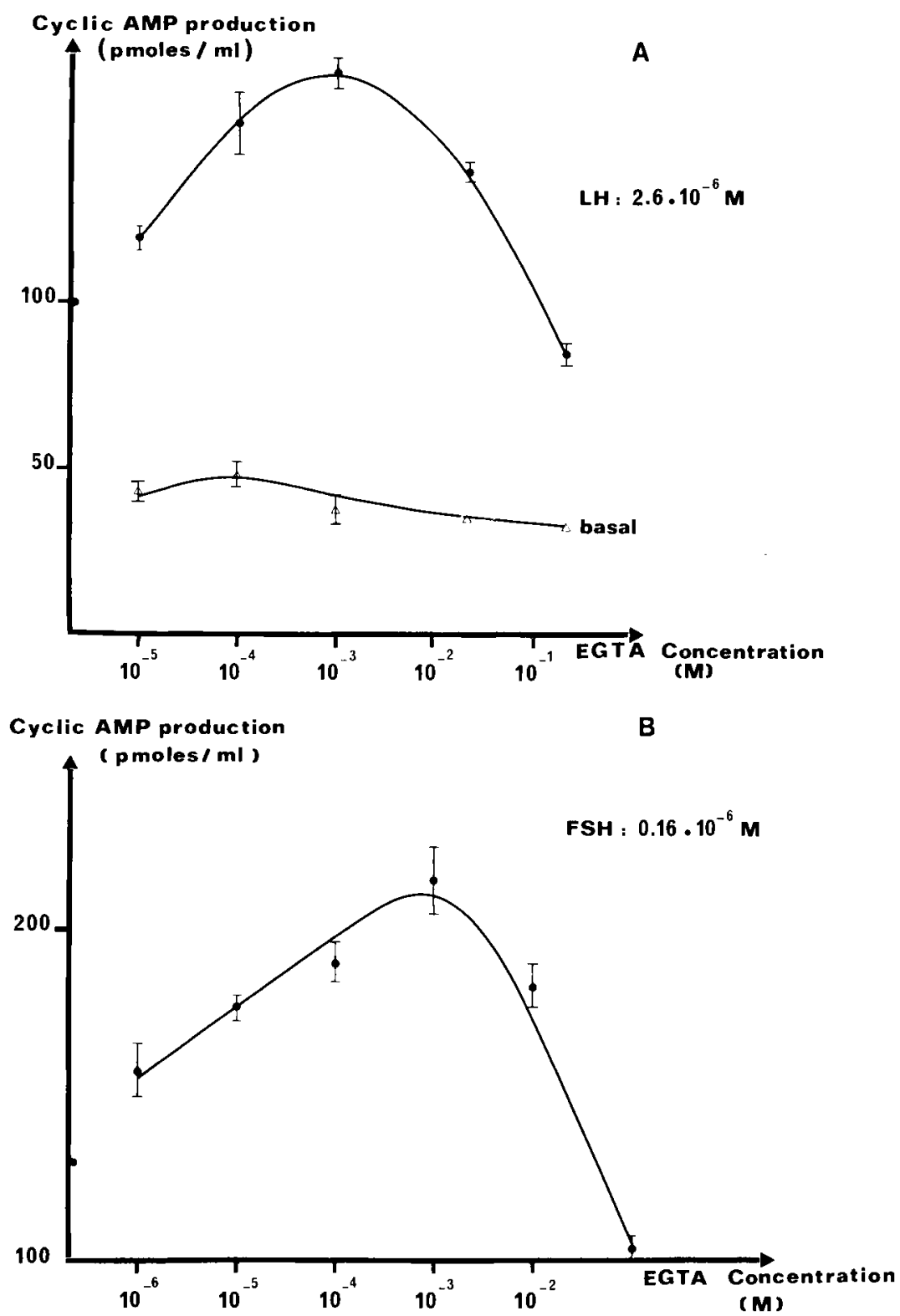

FIG. 2. - Effect of EGTA on cAMP production in rat ovary homogenates stimulated by different effectors : A - basal and LH-stimulated cAMP accumulation: B - stimulation by FSH : $\mathrm{C}$ - stimulation by $\mathrm{NaF} ; \mathrm{D}$ - stimulation by $\mathrm{Gpp}(\mathrm{NH}) \mathrm{p}(\therefore-1)$ and $\mathrm{Gpp}(\mathrm{NH}) \mathrm{p}\left(2.10^{-4} \mathrm{M}\right)+$ LH $\left(2.10^{-6} \mathrm{M}\right)(-1)$. These values represent the means \pm SEM of three determinations. 
different pattern was found than that shown in figure 1 concerning the effect of $\mathrm{Ca}^{++}$addition. In these conditions, the addition of $\mathrm{Ca}^{++}$gave a biphasic curve (fig. 3, A, B) when adenylate cyclase was stimulated by either $\mathrm{LH}$ or $\mathrm{Gpp}(\mathrm{NH}) \mathrm{p}$ : the enhancement of cAMP production at low concentrations of added $\mathrm{Ca}^{++}$, followed by an inhibition at higher concentrations, similar to that obtained in homogenates that were not treated by EGTA. These results suggest that the
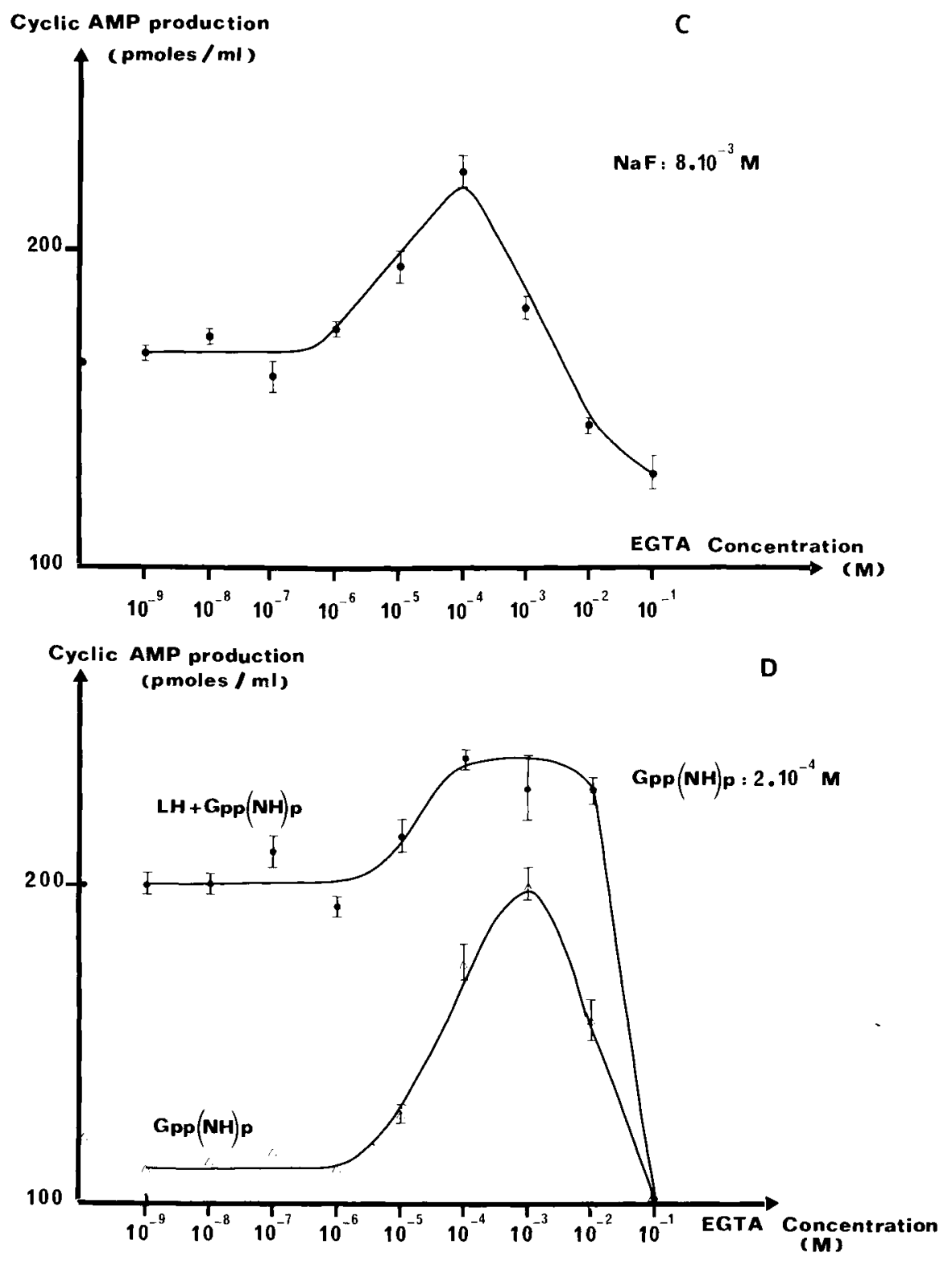

FIG. 2. - continued. 
EGTA treatment certainly eliminated the excess $\mathrm{Ca}^{++}$ions present in the homogenates and perhaps some endogenous calmodulin bound to the membranes.



cyclic AMP production (pmoles / ml)

B

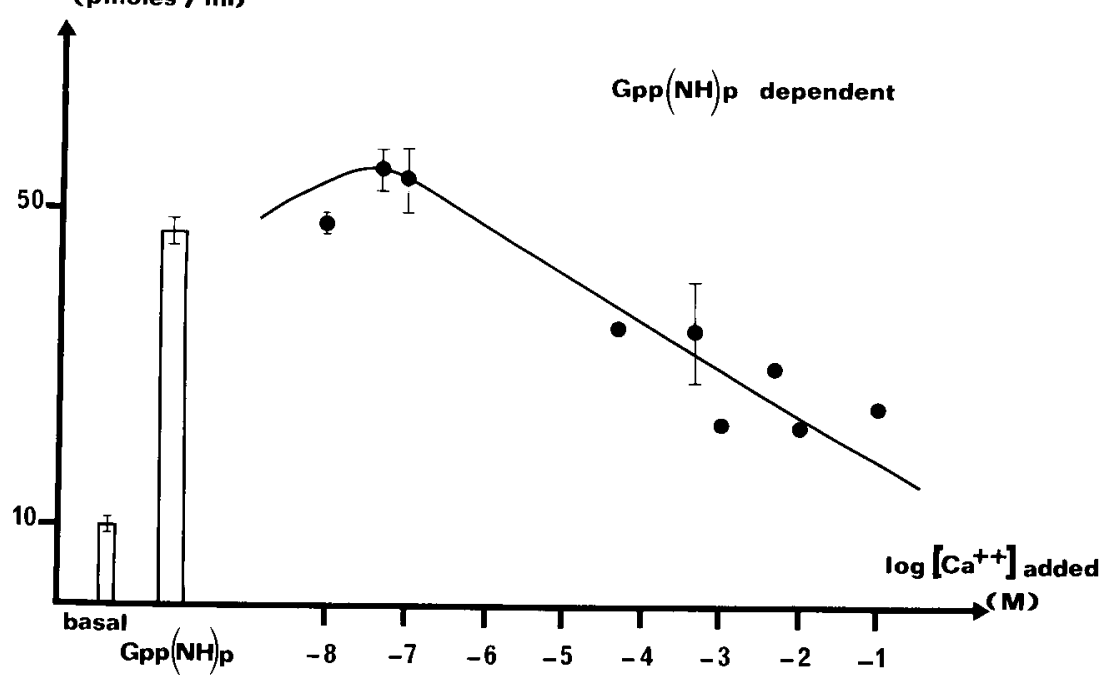

FIG 3. - cAMP production in rat ovary homogenates stimulated by a maximal dose of $L H$ $\left(2.10^{-6} \mathrm{M}\right)(\mathrm{A})$ or $\mathrm{Gpp}(\mathrm{NH}) p\left(2.10^{4} \mathrm{M}\right)(\mathrm{B})$ in the presence of $10^{-4} \mathrm{M}$ EGTA added to the medium and various concentrations of $\mathrm{Ca}^{2}$. The two blanks shown correspond to basal production and the production induced by the effectors without $\mathrm{Ca}^{2}+$ addition Results are means \pm SEM of four determinations. 
Influence of phenothiazine drugs on adenylate cyclase activation. - The addition of trifluoperazine (TFP) or pimozide to rat ovary homogenates markedly decreased the LH-stimulated production of cAMP in a concentration-dependent manner (fig. 4). A significant decrease of the $\mathrm{LH}$ response was observed at a

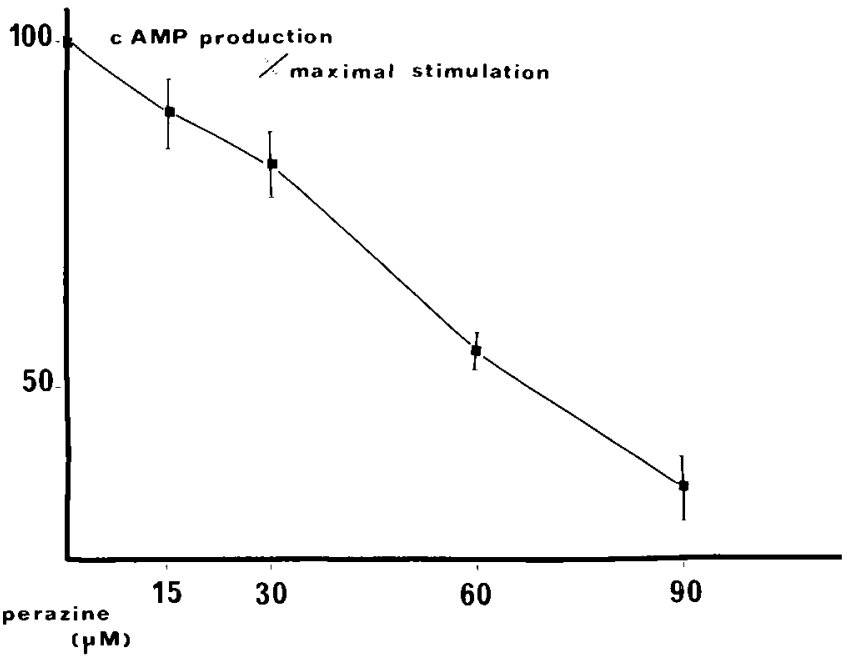

FIG.4. - Influence of the addition of different concentrations of trifluoperazine on LH-stimulated cAMP production in rat ovary homogenates. Each point represents the means \pm SEM of six experiments.

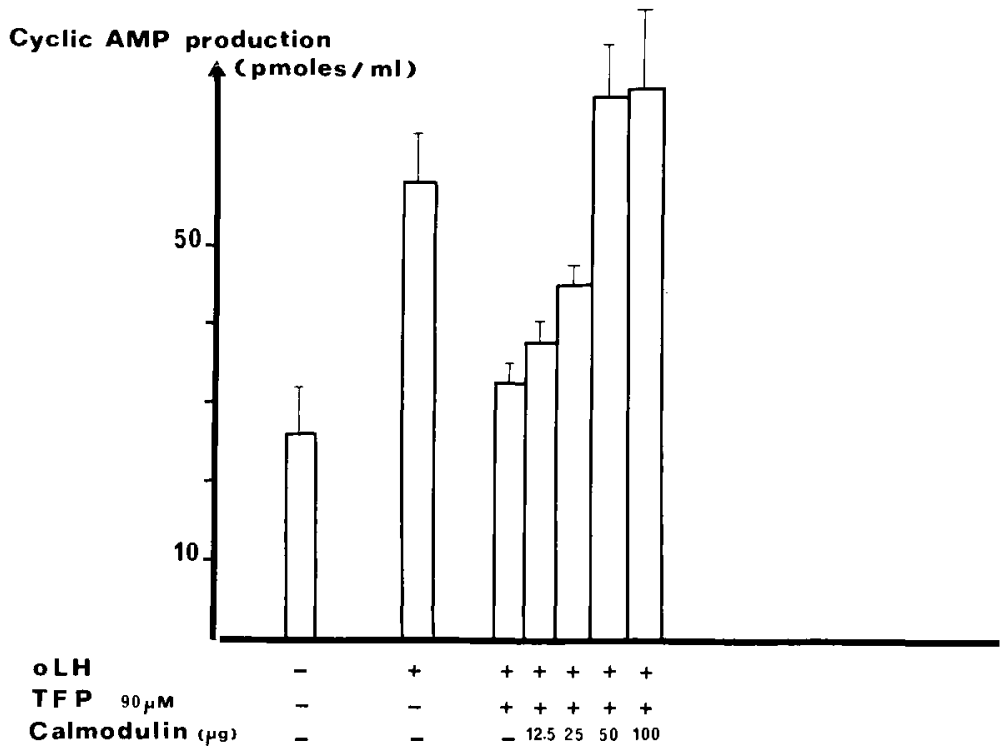

FIG. 5. - Reactivation of adenylate cyclase activity inhibited by $90 \mu M$ TFP by the addition of different concentrations of calmodulin. Results shown are the means \pm SEM of three determinations. 
concentration of $30 \mu \mathrm{M}$ TFP with virtually complete inhibition at $90 \mu \mathrm{M}$. Experiments performed in the presence of pimozide led to similar results but a higher concentration ( $600 \mu \mathrm{M}$ for $60 \%$ inhibition) was required to induce a similar degree of inhibition.

Figure 5 shows that the inhibitory effect induced by TFP was reversed by adding bovine brain calmodulin. The rate of CAMP production induced by $\mathrm{LH}$ in untreated homogenates was attained in a medium containing $90 \mu \mathrm{m}$ of TFP and $50 \mu \mathrm{g}$ of calmodulin, suggesting that TFP was preferentially bound to this protein.

Effect of calmodulin addition on ovarian adenylate cyclase stimulation. - The effect of increasing the concentration of $\mathrm{Ca}^{++}$-free calmodulin on $\mathrm{LH}$-dependent ovary adenylate cyclase is illustrated in figure 6 . Since the incubation medium contained, as previously shown, an excess of $\mathrm{Ca}^{++}$ions, the preparation of calmodulin was previously deprived of $\mathrm{Ca}^{++}$by dialysis against $1 \mathrm{mM}$ EGTA, followed by extensive dialysis against $10 \mathrm{mM}$ Tris- $\mathrm{HCl}$ buffer, $\mathrm{pH}$ 7.4. cAMP production induced by $\mathrm{LH}$ showed a moderate and significant increase in proportion to the amount of calmodulin added.

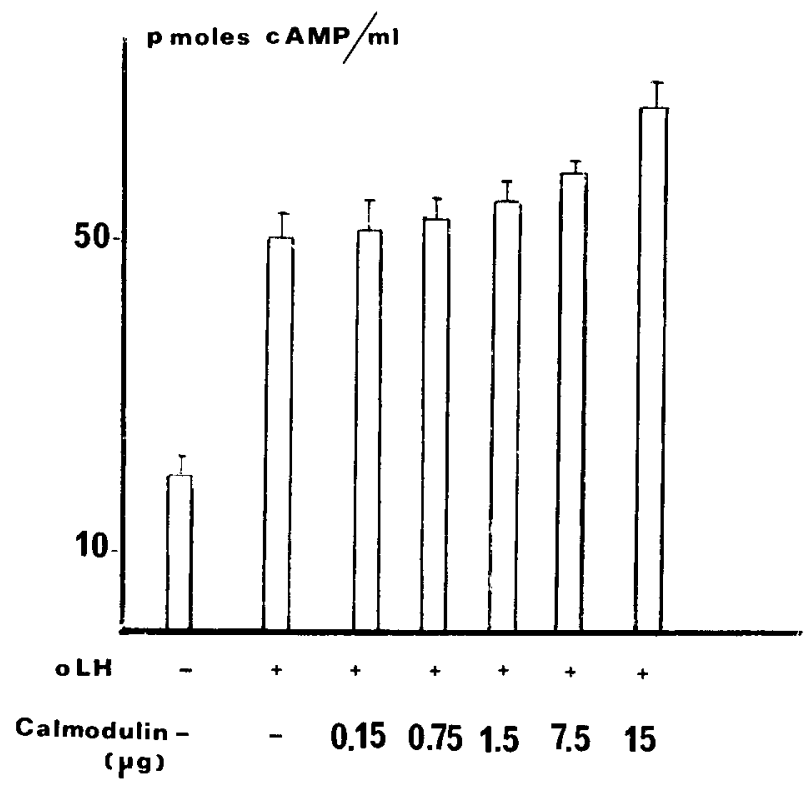

FIG. 6. - Effect of increasing concentrations of $\mathrm{Ca}^{2+}$-deprived calmodulin on cAMP accumulation stimulated by $2.610^{-6} \mathrm{MLH}$ in rat ovary homogenates. $\mathrm{Ca}^{++}$-deprived calmodulin was used because the homogenates contained supraoptimal $\mathrm{Ca}^{+}+$concentrations (see text). Each point represents the means \pm SEM of three determinations.

When a calmodulin preparation oversaturated with $\mathrm{Ca}++$ was added to the incubation medium, the results observed were less clear-cut because the inhibitory effect of excess $\mathrm{Ca}^{++}$might have compensated for the stimulatory effect of calmodulin. 
On the other hand, this enhancement of LH-dependent adenylate cyclase stimulation observed in the presence of calmodulin, though moderate, appeared to be quite specific and not related to $\mathrm{Ca}^{++}$chelation. The other two $\mathrm{Ca}^{++}$ binding proteins, parvalbumin and troponin, previously deprived of this cation in the same manner as calmodulin, had no effect on adenylate cyclase activity even when the concentration used was 20 times higher than in the case of calmodulin.

\section{Discussion.}

In the present paper we have studied the involvement of $\mathrm{Ca}^{++}$ions and calmodulin in the regulation of adenylate cyclase activity in juvenile rat ovaries. The addition of $\mathrm{Ca}^{+}+$ions to rat ovary homogenates produced a concentrationdependent inhibition of juvenile rat ovarian adenylate cyclase at concentrations higher than $10^{-5} \mathrm{M}$. It has been shown that in most cells $\mathrm{Ca}^{++}$ions inhibit adenylate cyclase activity at $\mu \mathrm{M}$ concentrations and above (Klee et al., 1980), and several studies have provided data which suggest that $\mathrm{Ca}^{+}+$-dependent inhibition of adenylate cyclase activity is due to the binding of this cation to an allosteric divalent cation-binding site located on the catalytic subunit of the enzyme (Hanski et al., 1977 ; Steer and Levitzki, 1975).

The enhancement of ovarian adenylate cyclase activity observed in the presence of EGTA suggests that the homogenates contained excess $\mathrm{Ca}^{+}+$and that the optimal concentration of this ion needed to obtain maximal stimulation of the enzyme was much lower than the $\mathrm{Ca}^{+}+$content in the homogenates. The curves illustrating the dependence of the response to EGTA concentration were similar when adenylate cyclase activity was stimulated by $\mathrm{LH}, \mathrm{FSH}, \mathrm{NaF}$ or $\mathrm{Gpp}(\mathrm{NH}) \mathrm{p}$. When the homogenates were previously deprived of $\mathrm{Ca}^{+}+$by treatment with $2 \mathrm{mM}$ EGTA, followed by extensive washing in Tris- $\mathrm{HCl}$ buffer, the results were different: some $\mathrm{Ca}^{++}$had to be added to attain optimal conditions for the stimulation of adenylate cyclase by $L H$ or $G p p(N H) p$, even though $\mathrm{Ca}^{++}$excess is inhibitory. $\mathrm{Ca}^{++}$is therefore necessary for enzyme activity.

Both TFP and pimozide, two potent calmodulin blocking agents (Levin and Weiss, 1976, 1979; Cheung, 1980), suppressed the LH-stimulated adenylate cyclase activity in a dose-related manner. In general, phenothiazine drugs act as inhibitors of hormonally stimulated adenylate cyclase in a variety of tissues (Means and Dedman, 1980). Even though some non-specific effects of these drugs have been reported, they generally appear at higher concentrations than those used in our experiments (Wolff and Jones, 1970 ; Corps et al., 1982).

Calmodulin compensated for the effects of these drugs : cAMP accumulation inhibited by TFP could be recovered by the addition of exogenous calmodulin. Furthermore, the addition of $\mathrm{Ca}^{++}$-free calmodulin alone stimulated adenylate cyclase response. This effect was moderate but clearly significant. It is well known that ovarian tissue contains high concentrations of calmodulin (Maizels and Jungmann, 1983), and it can therefore be presumed that since most of the adenylate cyclase was saturated by this protein, the effect of exogenous 
calmodulin addition would not be spectacular. Numerous adenylate cyclase systems have been shown to be unresponsive or weakly responsive to calmodulin.

The action of calmodulin that we observed did not seem to be due simply to the chelation of $\mathrm{Ca}^{++}$by the protein, as in the case of EGTA, since other $\mathrm{Ca}^{++}$ binding proteins (parvalbumin or troponin) were unable to induce the same results.

The involvement of $\mathrm{Ca}^{++}$in gonadal steroidogenesis has been studied by several authors who have shown that this cation is involved in two steps of the steroidogenic pathway : cAMP accumulation and steroid biosynthesis. Veldhuis and Klase $\left(1982 \mathrm{a}\right.$, b) reported that $\mathrm{Ca}^{+}+$deprivation impaired the stimulation of cAMP production by LH in isolated granulosa cells. Lahav et al. (1983) using corpora lutea reported that the response to $\mathrm{LH}$, in terms of cAMP accumulation, was not significantly affected by eliminating $\mathrm{Ca}^{+}+$from the media. Dorflinger et al. (1984) have shown that $\mathrm{Ca}^{+}+$is an inhibitor of $\mathrm{LH}$-sensitive adenylate cyclase in rat luteal cells. However, Evain et al. (1979) working on crude ovary cell membranes of Chinese hamster observed that adenylate cyclase activity increased when EGTA was added, apparently due to the removal of the $\mathrm{Ca}^{++}$ions or other heavy metals ; the addition of $\mathrm{Ca}^{+}+$alone to the incubation media inhibited the adenylate cyclase. These results which are similar to ours show that the membrane preparation, as our ovarian preparation, probably contained excess $\mathrm{Ca}^{++}$ions. The most outstanding difference between their results and ours concerns the effect of calmodulin addition which, according to them, inhibits basal and GTP-stimulated adenylate cyclase activity. We think that the addition of $\mathrm{Ca}^{+}+$oversaturated calmodulin to their medium, which contained excess $\mathrm{Ca}^{++}$, could explain these results.

Conc/usion. - The result reported in the present paper demonstrate the modulation of adenylate cyclase activity of rat ovary homogenate by $\mathrm{Ca}^{+}+$and calmodulin. Adenylate cyclase activity was stimulated by the addition of $\mathrm{Ca}^{++}$ ions only when the homogenates were previously washed with EGTA. Our results suggest that $\mathrm{Ca}^{++}$regulation of ovarian adenylate cyclase is mediated by calmodulin.

Reçu en juillet 1985.

Accepté en octobre 1985.

Acknowledgements. - We wish to thank the National Pituitary Agency (Bethesda, MD, USA) for the gift of ovine FSH. TFP was kindly provided by the Theraplix Laboratory and pimozide by the Janssen Laboratories. Ovine LH prepared by $\mathrm{Mr}$. Poissonnier was kindly offered by Dr. Jutisz. We acknowledge the help of I.N.R.A. (contracts No. 8145 and 8157 ). 
Résumé. Régulation par le calcium et la calmoduline de l'activité de l'adénylate cyclase ovarienne de ratte immature.

Le rôle des ions $\mathrm{Ca}^{2}+$ et de la calmoduline dans la régulation de l'activité de l'adénylate cyclase ovarienne de ratte immature a été étudié. La production d'AMPc basale et stimulée par la LH est inhibée lorsqu'on ajoute au milieu d'incubation une concentration en ions $\mathrm{Ca}^{2+}$ supérieure à $10^{-5} \mathrm{M}$. Inversement, I'EGTA (jusqu'à $10^{-3} \mathrm{M}$ ) augmente la production d'AMPc (basale et stimulée par LH, FSH, NaF et Gpp(NH)p) ; des concentrations supérieures en chélateur provoquent une inhibition de la production d'AMPc. Cependant, lorsque les homogénats sont préalablement débarrassés des ions $\mathrm{Ca}^{2}+$ (après traitement avec un tampon contenant de l'EGTA), on observe une réponse biphasique à $\mathrm{LH}$ et à $\mathrm{Gpp}(\mathrm{NH}) p$ en présence de concentrations croissantes de calcium : d'abord une augmentation de la production d'AMPc pour les faibles concentrations en ions $\mathrm{Ca}^{2+}$, puis une inhibition pour des concentrations plus élevées. Ces observations suggèrent d'une part que la concentration optimale de $\mathrm{Ca}^{2}+$ nécessaire pour obtenir une stimulation maximale de l'enzyme est inférieure au contenu en calcium des homogénats et d'autre part, qu'une concentration minimale de $\mathrm{Ca}^{2}+$ est nécessaire pour son activation.

En présence de concentrations micromolaires de trifluopérazine et de pimozide, deux puissants inhibiteurs de la calmoduline, la production d'AMPC stimulée par la LH est fortement diminuée. La réactivation peut être obtenue en ajoutant de la calmoduline au milieu d'incubation.

L'addition de calmoduline exogène exempte d'ions $\mathrm{Ca}^{2}+\left(\right.$ à $10^{-6} \mathrm{M}$ ) entraîne une augmentation spécifique et significative de l'accumulation d'AMPc induite par des doses optimales de $\mathrm{LH}$. Ces résultats suggèrent que les ions calcium régulent l'activité de l'adényle cyclase d'ovaires de rat. Un double effet est observé : un effet stimulant pour de faibles concentrations en $\mathrm{Ca}^{2}+$, régulé par la calmoduline, suivi par une action inhibitrice pour des concentrations plus élevées (non physiologiques) de ce cation.

\section{Références}

CHEUNG W., 1980. Calmodulin plays a pivotal role in cellular regulation Science, 207, 19-27.

CORPS A. N., HESKETH T. R., METCALFE J. C., 1982. Limitations on the use of phenothiazines and local anaesthetics as indicators of calmodulin function in intact cells. FEBS Letters, 138 , 280-284.

DORFLINGER L. J., ALBERT P. J., WILLIAMS A. T., BEHRAM H. R., 1984. Calcium is an inhibitor of luteinizing hormone-sensitive adenylate cyclase in the luteal cell. Endocrinology, 114, 1208-1216.

EVAIN D., KLEE C. B., ANDERSON W. B., 1979. Chinese hamster ovary cell population density affects intracellular concentrations of calcium-dependent regulator and ability of regulator to inhibit adenylate cyclase activity. Proc. nat. Acad. Sci. (U.S. A.), 76, 3962-3966.

GILMAN A. G., 1970. A protein binding assay for adenosine 3'5' cyclic monophosphate. Proc. nat. Acad. Sci. (U.S.A.), 67, 305-312.

HANSKI E., SEVILLA N., LEVITZKI A., 1977. The control of adenylate cyclase by calcium in turkey erythrocyte ghosts. Eur. J. Biochem., 76, 513-520.

JUTISZ M., COURTE C., 1968. Hormone luteinisante (LH) de mouton. Obtention à l'état apparemment homogène, étude physio-chimique et biologique. Gen. comp Endocrinol., 11, 562574.

KLEE C. B., CROUCH T. H., RICHMAN P. G., 1980. Calmodulin. Ann. Rev. Biochem., 49, 489-515.

LAHAV M., WEISS E., RAFAELOFF R., BARZILAI D., 1983. The role of calcium ion on luteal function in the rat. J. Steroid Biochem., 19, 805-810.

LEVIN R. M., WEISS B., 1976. Mechanism by which psychotropic drugs inhibit adenosine 3'5' -monophosphate phosphodiesterase. Mol. Pharmacol., 12, 581-589. 
LEVIN R. M., WEISS B., 1979. Selective binding of antipsychotic and other psychoactive agents to the calcium-dependent activator of cyclic nucletotide phosphodiesterase. J. Pharmaco/. exp. Ther., 208, 454-459.

MAIZELS E. T., JUNGMANN R. A., 1983. $\mathrm{Ca}^{2+-}$-calmodulin-dependent phosphorylation of soluble and nuclear proteins in the rat ovary. Endocrinology, 112, 1895-1901.

MEANS A. R., DEDMAN J. R., 1980. Calmodulin : an intracellular calcium receptor. Nature, 285, 73-77.

PINKUS L. M., SULIMOVICI S., SUSSER F. I., ROGINSKY M. S., 1983. Involvement of calmodulin in the regulation of adenylate cyclase activity in guinea-pig enterocytes. Biochim. biophys. Acta, 762, 552-559.

STEER M. L., LEVITZKI A., 1975. The interaction of cathecolamines, $\mathrm{Ca}^{++}$and adenylate cyclase in intact turkey erythrocyte. Arch. Biochem. Biophys., 167, 371-376.

TERTRIN-CLARY C., ROY M., de la LLOSA P., 1980. Nitroguanidyl-lutropin, a derivative which inhibits the stimulation of ovarian adenylate cyclase by lutropin. FEBS Letters, 118, 77-80.

TSANG B. K., CARNEGIE J. A., 1983. Calcium requirement in the gonadotropic regulation of rat granulosa cell progesterone production. Endocrinology, 113, 763-769.

VELDHUIS J. D., KLASE P. A., 1982a. Mechanism by which calcium ions regulate the steroidogenic actions of luteinizing hormone in isolated ovarian cells in vitro. Endocrinology, 111, 1-6.

VELDHUIS J. D., KLASE P. A., 1982b. Calcium ions modulate hormonally stimulated progesterone production in isolated ovarian cells. Biochem. J., 202, 381-386.

WOLFF J., JONES A. B., 1970 . Inhibition of hormone-sensitive adenylcyclase by phenothiazines. Proc. nat. Acad. Sci. (U.S.A.), 65, 454-459. 